\title{
Activation of MMP-9 by Human Lung Epithelial Cells in Response to the Cystic Fibrosis-Associated Pathogen Burkholderia Cenocepacia Reduced Wound Healing in Vitro
}

\author{
Ciara Wright ] \\ Institute of Technology Tallaght, ciara.wright@medivice.ie \\ Ruth Pilkington \\ Institute of Technology Tallaght, ruth.pilkington@tudublin.ie \\ Máire Callaghan \\ Institute of Technology Tallaght, maire.callaghan@tudublin.ie
}

See next page for additional authors

Follow this and additional works at: https://arrow.tudublin.ie/ittsciart

Part of the Biochemistry, Biophysics, and Structural Biology Commons, Cell Biology Commons, Immunology of Infectious Disease Commons, and the Pathogenic Microbiology Commons

\section{Recommended Citation}

Wright, Clara et al: Activation of MMP-9 by Human Lung Epithelial Cells in Response to the Cystic FibrosisAssociated Pathogen Burkholderia Cenocepacia Reduced Wound Healing in Vitro.Am J Physiol Lung Cell Mol Physiol. 2011 Oct ;301 (4):L575-86 21743026

This Article is brought to you for free and open access by the School of Science and Computing at ARROW@TU Dublin. It has been accepted for inclusion in Articles by an authorized administrator of ARROW@TU Dublin. For more information, please contact arrow.admin@tudublin.ie, aisling.coyne@tudublin.ie, gerard.connolly@tudublin.ie. Funder: HEA PRTLI Cycle 4

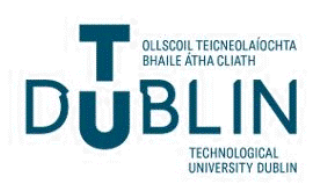




\section{Authors}

Ciara Wright ], Ruth Pilkington, Máire Callaghan, and Siobhan McClean

This article is available at ARROW@TU Dublin: https://arrow.tudublin.ie/ittsciart/4 


\section{Activation of MMP-9 by human lung epithelial cells in response to the cystic fibrosis-associated pathogen Burkholderia cenocepacia reduced wound healing in vitro}

Ciara Wright, Ruth Pilkington, Máire Callaghan and Siobhán McClean

Am J Physiol Lung Cell Mol Physiol 301:L575-L586, 2011. First published 8 July 2011; doi: 10.1152 /ajplung.00226.2010

You might find this additional info useful...

This article cites 51 articles, 27 of which you can access for free at:

http://ajplung.physiology.org/content/301/4/L575.full\#ref-list-1

Updated information and services including high resolution figures, can be found at: http://ajplung.physiology.org/content/301/4/L575.full

Additional material and information about American Journal of Physiology - Lung Cellular and

Molecular Physiology can be found at:

http://www.the-aps.org/publications/ajplung

This information is current as of December 12, 2012. 


\title{
Activation of MMP-9 by human lung epithelial cells in response to the cystic fibrosis-associated pathogen Burkholderia cenocepacia reduced wound healing
} in vitro

\author{
Ciara Wright, ${ }^{1,2}$ Ruth Pilkington, ${ }^{1}$ Máire Callaghan,,${ }^{1,2}$ and Siobhán McClean ${ }^{1,2}$ \\ ${ }^{1}$ Centre of Microbial Host Interactions and ${ }^{2}$ Centre of Applied Science for Health, Institute of Technology Tallaght, Tallaght, \\ Dublin, Ireland
}

Submitted 7 July 2010; accepted in final form 6 July 2011

Wright C, Pilkington R, Callaghan M, McClean S. Activation of MMP-9 by human lung epithelial cells in response to the cystic fibrosisassociated pathogen Burkholderia cenocepacia reduced wound healing in vitro. Am J Physiol Lung Cell Mol Physiol 301: L575-L586, 2011. First published July 8, 2011; doi:10.1152/ajplung.00226.2010.—Burkholderia cepacia complex is a group of bacterial pathogens that cause opportunistic infections in cystic fibrosis $(\mathrm{CF})$. The most virulent of these is Burkholderia cenocepacia. Matrix metalloproteinases (MMPs) are upregulated in CF patients. The aim of this work was to examine the role of MMPs in the pathogenesis of B. cepacia complex, which has not been explored to date. Real-time PCR analysis showed that $B$. cenocepacia infection upregulated MMP-2 and MMP-9 genes in the $\mathrm{CF}$ lung cell line CFBE41o- within $1 \mathrm{~h}$, whereas MMP-2, -7 , and -9 genes were upregulated in the non-CF lung cell line $16 \mathrm{HBE} 14 \mathrm{o}-$. Conditioned media from both cell lines showed increased MMP-9 activation following $B$. cenocepacia infection. Conditioned media from $B$. cenocepacia-infected cells significantly reduced the rate of wound healing in confluent lung epithelia $(P<0.05)$, in contrast to conditioned media from Pseudomonas aeruginosa-infected cells, which showed predominant MMP-2 activation. Treatment of control conditioned media from both cell lines with the MMP activator 4-aminophenylmercuric acetate (APMA) also resulted in clear activation of MMP-9 and to a much lesser extent MMP-2. APMA treatment of control media also delayed the repair of wound healing in confluent epithelial cells. Furthermore, specific inhibition of MMP-9 in medium from cells exposed to B. cenocepacia completely reversed the delay in wound repair. These data suggest that MMP-9 plays a role in the reduced epithelial repair observed in response to $B$. cenocepacia infection and that its activation following $B$. cenocepacia infection contributes to the pathogenesis of this virulent pathogen.

microbial pathogenesis; Burkholderia cepacia complex; matrix metalloproteinases; epithelial wound repair

BURKHOLDERIA CEPACIA COMPLEX is an opportunistic bacterial pathogen that chronically colonizes the lungs of patients with either cystic fibrosis (CF) or chronic granulomatous disease (CGD) and causes life-threatening infections in both populations $(31,32,44)$. It is a group of 17 related species that are inherently resistant to antibiotic treatment $(48,49)$. CF is a genetically inherited disorder caused by mutations in the cystic fibrosis transmembrane regulator (CFTR), a chloride channel. A common feature of $\mathrm{CF}$ is chronic opportunistic respiratory infections that patients acquire throughout their lives, resulting in a continuous cycle of infection and inflammation that gradually damages the lungs, thereby reducing lung function. Although Pseudomonas aeruginosa is the most commonly ac-

Address for reprint requests and other correspondence: S. McClean, Institute of Technology Tallaght Dublin, Old Blessington Rd., Tallaght, Dublin 24, Ireland (e-mail: siobhan.mcclean@ittdublin.ie). quired pathogen in $\mathrm{CF}$ patients, other pathogens, including $B$. cepacia complex, can also colonize and contribute to lung inflammation and damage (31). Although strict segregation measures have reduced the incidence of $B$. cepacia complex infection, two species, B. cenocepacia and B. multivorans, can be acquired from the environment, and patient-to-patient transmissibility is still an issue $(3,4,31,37)$. Of these, $B$. cenocepacia is particularly virulent. Jones et al. (22) have demonstrated that CF patients with $B$. cenocepacia infection had a shorter survival time than those with $P$. aeruginosa or $B$. multivorans infection.

Matrix metalloproteinases (MMPs) are a group of related but distinct enzymes that regulate various inflammatory and repair processes. They are either secreted or anchored to the cell surface and therefore their activity is directed against membrane proteins or extracellular proteins, including inflammatory mediators (40). Many MMPs, such as collagenase-1 and -3 (MMP-1 and MMP-13, respectively), stromelysins-1, -2, -3 (MMPs-3, -10, and -11), and gelatinase-B (MMP-9), are not expressed in normal healthy resting tissues or are only barely detectable (39). Matrilysin (MMP-7) is expressed on the wounded edge or within injured epithelial cells of the lung and is required for reepithelialization, but it is also expressed in the noninjured and noninflamed epithelium in adult tissues (40). In vitro and ex vivo studies have shown that MMP-9 also plays a role in reepithelization in the lung (29). Dysregulation of metalloproteinases has also been associated with inflammation and tissue damage $(11,39,40)$. MMPs are also upregulated in the CF lung $(23,30)$.

The induction and activation of MMP-7 in mucosal epithelia is highly sensitive to the presence of virulent bacteria, such as $P$. aeruginosa, but not Staphylococcus aureus, Haemophilus influenzae, or Klebsiella pneumoniae. The induced expression of MMP-7 in Calu-3 cells was attributed to $P$. aeruginosa flagellin (30). P. aeruginosa virulence factors, most likely elastase, have also been shown to overactivate host MMP-2 and prevent the formation of tight junctions during repair (7). MMP-7 has been shown to degrade E-cadherin (35), whereas MMP-9 plays a role in claudin turnover $(20,50)$, suggesting that host MMPs could play a role in disruption of tight junction integrity following infection because they are regulated by cytokines, including IL-13 (28). MMPs have been shown to be responsible for early dissemination of Mycobacterium tuberculosis in mice, and MMP-9 has been shown to play a causative role in granuloma formation during $M$. tuberculosis infection (45). The role of MMPs in the pathogenesis of the CF pathogen $B$. cepacia complex has not been explored to date, and therefore we investigated whether MMP expression plays 
a role in B. cepacia complex host-cell response in lung epithelia.

\section{MATERIALS AND METHODS}

Materials. All materials were purchased from Sigma, with the following exceptions: TRIzol, Superscript III, Taq polymerase and Ultroser G (Invitrogen), Vitrogen (Nutacon); MMP-9 inhibitor I (Merck Chemicals), SYBR green PCR Mastermix (Roche), and Fluorokine E human MMP-9 fluorescent assay kit (R\&D Systems).

Cell culture. Both human lung epithelial cell lines, 16HBE14oand CFBE41o-, were a generous gift from Dr. Dieter Gruenert, University of California, San Francisco. The 16HBE14o- cells (passage 2.85 to $\sim 2.105$ ) were maintained on Vitrogen/fibronectin-coated flasks in minimum essential medium (MEM) supplemented with $1 \%$ L-glutamine, $1 \%$ penicillin-streptomycin, and 10\% FBS. (6) CFBE41o- cells (passage 4.85 to 4.105 ) were derived from a $\mathrm{CF}$ patient that was homozygous negative for the most common CFTR mutation, $\Delta \mathrm{F} 508$, and were also maintained on coated flasks in the same medium, supplemented with $1 \%$ nonessential amino acids (15). Confluent monolayers of $16 \mathrm{HBE} 14 \mathrm{o}-$ cells were obtained by seeding at $2 \times 10^{5}$ cells $/ \mathrm{ml}$ in $1 \mathrm{ml}$ in 24 -well plates for $48 \mathrm{~h}$ prior to zymography. CFBE41o- cells were seeded at $1 \times 10^{5}$ cells $/ \mathrm{ml}$ in 1 $\mathrm{ml}$. Medium was changed at $24 \mathrm{~h}$ and replaced with complete medium without antibiotics. A confluent monolayer was present at $48 \mathrm{~h}$. Polarized monolayers were also prepared by seeding $16 \mathrm{HBE} 14 \mathrm{o}-$ or CFBE41o - cells at $7 \times 10^{5} / \mathrm{cm}$ on coated Transwell polycarbonate filters. The cells were incubated overnight before removal of the apical medium, grown for 6 days with an air-liquid interface, and fed basolaterally on alternate days, with medium in which the FBS was replaced with $2 \%$ Ultroser $\mathrm{G}$ (27).

Bacterial infection of lung epithelial cells. The two B. cepacia complex strains used in this study, Burkholderia cenocepacia strain (BC7) and Burkholderia multivorans strain (LMG13010), were both obtained from the Belgian Co-ordinated Collections of Micro-organisms, University of Ghent, Belgium and routinely grown on $B$. cepacia-specific agar (18). P. aeruginosa (PAO1) was used as a reference strain and was obtained from American Type Culture Collection. Overnight bacterial cultures were grown in Luria-Bertani broth to an $\mathrm{OD}_{600 \mathrm{~nm}}$ of 0.6 and then diluted to a given concentration. A suspension of $2 \times 10^{7} \mathrm{CFU} / \mathrm{ml}$ was made up in MEM and added to the confluent cultures of lung epithelial cells at a multiplicity of infection of 50:1. The plate was centrifuged to settle bacteria for $5 \mathrm{~min}$ at $700 \mathrm{~g}$ and incubated at $37^{\circ} \mathrm{C}$ and $5 \% \mathrm{CO}_{2}$ for the appropriate time.

Isolation of RNA and cDNA biosynthesis. Following bacterial infections, medium was removed, cells were directly lysed in TRIzol, and total RNA was isolated according to manufacturer's instructions. An aliquot of $1 \mu \mathrm{g}$ of RNA (A260/280 >1.7) was used to synthesize by cDNA using Superscript III according to the manufacturer's instructions.

Expression of MMP genes. Initial studies to explore the effects of bacteria on transcription of metalloproteinase genes in CFBE41o- and 16HBE14o - cells were carried out semiquantitatively over a 24-h period. A selection of MMP genes, MMP- 2, 3, 7, and 9 cDNAs $(1 \mu \mathrm{l})$, was amplified in a $50-\mu$ l reaction by reverse transcriptase PCR (RTPCR). The primers used were as follows: GAPDH forward $5^{\prime}-$ CCCCTTCATACCCTCACGTA-3', reverse 5'-ACAAGCTTCCCGTTCTCAG-3'; MMP-2 forward 5'-AGGGCACATCCTATGACAGC-3', reverse 5'-CCTTCTGAGTTCCCACCAAC-3'; MMP-3 forward 5'-TCCGCCTGTCTCAAGATGAT-3', reverse 5'-CCAAAAGTGCCTGTCTTTA-3'; MMP-7 forward 5'-TGTATGGGGAACTGCTGACA-3', reverse 5'-AGACTGCTACCATCCGTCCA3'; MMP-9 forward 5'-CAGTCCACCCTTGTGCTCTT-3', reverse 5' AGGGACAGTTGCTTCTGGAG-3'.

PCR was carried out for 35 cycles of denaturation $\left(30 \mathrm{~s}, 95^{\circ} \mathrm{C}\right)$, annealing $\left(30 \mathrm{~s}, 58^{\circ} \mathrm{C}\right)$, and elongation $\left(45 \mathrm{~s}, 72^{\circ} \mathrm{C}\right)$.
Real-time PCR was carried out by using the same primers as those for regular PCR together with FastStart Universal SYBR Mastermix (Roche) according to manufacturer's instructions at concentrations of $380 \mathrm{nM}$ for MMP primers and $190 \mathrm{nM}$ for GAPDH. The samples were amplified in triplicate on a 7300 Real-Time PCR System (Applied Biosystems) as follows: 40 cycles of denaturation $\left(15 \mathrm{~s}, 95^{\circ} \mathrm{C}\right)$ and annealing/elongation $\left(1 \mathrm{~min}, 66^{\circ} \mathrm{C}\right)$ were carried out. The threshold cycles $(\mathrm{Ct})$ for each primer set were obtained from triplicate samples and averaged. The delta $\mathrm{Ct}$ was the calculated difference between the average $\mathrm{Ct}$ for the target gene and the average $\mathrm{Ct}$ for GAPDH as a control for total starting RNA quantity. The delta-delta Ct method of calculation was then used to assess fold change in gene expression relative to the GAPDH gene.

Gelatin zymography. Gelatin zymography experiments were performed on conditioned media harvested from control untreated cells, from infected lung epithelial cells as described above, or from 4-aminophenylmercuric acetate (APMA)-treated supernatants to assess the level of MMP-2 and MMP-9 enzyme secreted. Conditioned media were harvested from cells at appropriate time points posttreatment and stored at $-80^{\circ} \mathrm{C}$ until use. A volume of $20 \mu \mathrm{l}$ of cellconditioned medium was mixed with $5 \times$ nonreducing Laemlli buffer (60 mM Tris-Cl, pH 6.8, 2\% SDS, $10 \%$ glycerol, $0.01 \%$ bromophenol blue) and loaded onto a $10 \%$ SDS-PAGE gel containing $0.1 \%$ gelatin. Samples were electrophoresed at $140 \mathrm{~V}$ for $90 \mathrm{~min}$ and then the gels were rinsed in distilled water and washed in two changes of $2.5 \%$ Triton-X 100 to remove SDS for $1 \mathrm{~h}$. Gels were then incubated for 24 $\mathrm{h}$ in digestion buffer (50 mM Tris $\left.\mathrm{pH} 8,0.5 \mathrm{mM} \mathrm{CaCl}_{2}, 5 \mu \mathrm{M} \mathrm{ZnCl}_{2}\right)$ at $37^{\circ} \mathrm{C}$. Bands were visualized by Coomassie blue staining for $1 \mathrm{~h}$ followed by destaining in methanol-acetic acid-water $(1: 1: 8)$ for 10 min. Gelatinase activity corresponded to areas of clearance of the gelatin from the gels. The images were captured on a SynGene G:box system (SynGene, Cambridge, UK) and the clear bands were analyzed by SynGene Gene Tools software. The activity of all samples were normalized by setting the activity of the relevant control to one, and the data were presented as the fold change in activity.

Determination of active and total MMP-9 secretion. The amount of total and active MMP-9 secreted was determined by using a Fluorokine E human MMP-9 fluorescent assay kit according to the manufacturer's instructions. Conditioned cell medium (diluted 1:10) or MMP-9 standard (200 $\mu$ l per well) were added to individual wells precoated with MMP-9-specific capture antibody, incubated for $2 \mathrm{~h}$, and washed four times. Total MMP-9 was determined in the presence of APMA, whereas no activator was added to wells to determine active MMP-9. The fluorogenic substrate was added for a further 18 $\mathrm{h}$ at $37^{\circ} \mathrm{C}$ and fluorescence generated was measured on a Thermo Fisher Varioskan Flash spectrophotometer. The MMP-9 activity was determined by comparison with a standard curve of the log of the active MMP-9 concentration against the log of the relative fluorescence units, determined by regression analysis.

Transepithelial resistance. For tight membrane integrity experiments, $16 \mathrm{HBE} 14 \mathrm{o}-$ or CFBE41o - cells were seeded at $7 \times 10^{5}$ cells/ml on Transwell filters that were precoated with Vitrogen. The integrity of the polarized monolayer was determined by measuring transepithelial electrical resistance (TER) using an epithelial voltohmmeter (World Precision Instruments) and corrected for the resistance value of the cell-free filter. Only polarized monolayers with a TER of $>200 \Omega / \mathrm{cm}^{2}$ over that of cell-free filters were used. TER values were $510 \pm 100$ and $484 \pm 56 \Omega / \mathrm{cm}^{2}$ for CFBE41o - cells and $16 \mathrm{HBE} 14 \mathrm{o}-$ cells, respectively. Cells were pretreated with GM6001 $(10 \mu \mathrm{M})$ for $30 \mathrm{~min}$ prior to, and during, the period of infection with bacteria; the TER was measured at regular intervals and compared with parallel wells exposed to bacterial alone or inhibitor alone.

Wound repair assays. Confluent monolayers of either $16 \mathrm{HBE} 14 \mathrm{o}-$ or CFBE410- were cultured as stated above with and without bacterial infection. Medium was replaced with MEM alone for $24 \mathrm{~h}$. Conditioned media from uninfected cells were harvested and treated with $1 \mathrm{mM}$ APMA (Sigma) or DMSO (solvent control) for $16 \mathrm{~h}$ at 
$37^{\circ} \mathrm{C}$ with gentle agitation to activate the MMPs released. Conditioned media either from infected cells or following APMA treatment were either used immediately or stored at $-80^{\circ} \mathrm{C}$ for use in zymography. To confirm the role of MMP-9, conditioned media from $B$. cenocepacia strain BC7-infected cells were also preincubated with 20 nM MMP-9 inhibitor 1 for $30 \mathrm{~min}$ prior to application. Confluent monolayers were also cultured for wounding. A wound was inflicted by scraping with a sterile pipette tip across the entire monolayer as described by Olsen et al. (38). Images of the wounds were captured via a microscope video eyepiece camera USB at time intervals, and the monolayers were replaced in the incubator at $37^{\circ} \mathrm{C}$ and $5 \% \mathrm{CO}_{2}$ between imaging. The distance between the cell migration fronts was measured by using an ocular measurement graticule at five predetermined points along the length of the scrape. The values are presented as repair of the wound in micrometers.

Statistical analysis. The data changes in transepithelial resistance and wound healing experiments for individual strains were compared with one-way ANOVA with Tukey's posttest for pairwise comparisons (Minitab). Two-tailed Student's $t$-test (assuming unequal variances) was used to compare the real-time PCR data of individual strains relative to the untreated negative control, densitometry analysis of zymograms, and fluorescence analysis of MMP-9 expression or activation relative to control cells. A $P$ value of $<0.05$ was deemed to be significant in each case.

\section{RESULTS}

Semiquantitative analysis of MMP gene expression indicated upregulation of MMP-2 and MMP-9 $m R N A$. To enable us to focus on the MMP genes of interest, the expression of MMP-2, 3, 7, and 9 genes was investigated in two independent cell lines in response to $B$. cepacia complex infection or $P$. aeruginosa strain PAO1 infection over a $24-\mathrm{h}$ period by semiquantitative PCR, initially. Both the $16 \mathrm{HBE} 14 \mathrm{o}-$ and CFBE41o- cell lines expressed all of the examined genes, albeit MMP-3 mRNA was expressed at very low levels and was barely detectable in CFBE41o- cells (Fig. 1, $A$ and $B$ ). Semiquantitative reverse transcriptase PCR suggested an upregulation of MMP-2 and MMP-9 mRNA at earlier time points in both of these cell lines, in response to infection with $B$. cenocepacia strain BC7, B. multivorans strain LMG13010, and $P$. aeruginosa strain PAO1. To confirm the upregulation of these genes as an early response to infection, the expression of these two genes was therefore further examined by real-time PCR at the earliest time point of $1 \mathrm{~h}$ only. Although no clear upregulation of MMP-7 gene expression was observed by PCR when normalized with GAPDH, previous studies on Calu-3 cells demonstrated MMP-7 upregulation following exposure to $P$. aeruginosa strain PAO1 (24); thus this was also included in further studies.

MMP-2 and MMP-9 mRNA upregulated in lung epithelial cells in response to $B$. cepacia complex infection. The apparent upregulation of MMP-2 and MMP-9 genes in the 16HBE14oand $\mathrm{CFBE} 41 \mathrm{o}-$ cell lines in response to exposure to B. cenocepacia strain BC7, B. multivorans strain LMG13010, or P. aeruginosa strain PAO1 was quantitatively examined by real-time PCR at the early time point of $1 \mathrm{~h}$ (Fig. 2). MMP-2 gene expression was increased within $1 \mathrm{~h}$ in both cell lines in response to $B$. cepacia complex infection. The B. cenocepacia strain BC7 upregulated MMP-2 gene expression in both 16HBE140cells (3-fold, $P<0.05$ ) and CFBE41o- cells (4-fold, $P<$ 0.01), thus having a somewhat greater effect on CFBE41ocells than on $16 \mathrm{HBE} 14 \mathrm{o}-$ cells. Although B. multivorans
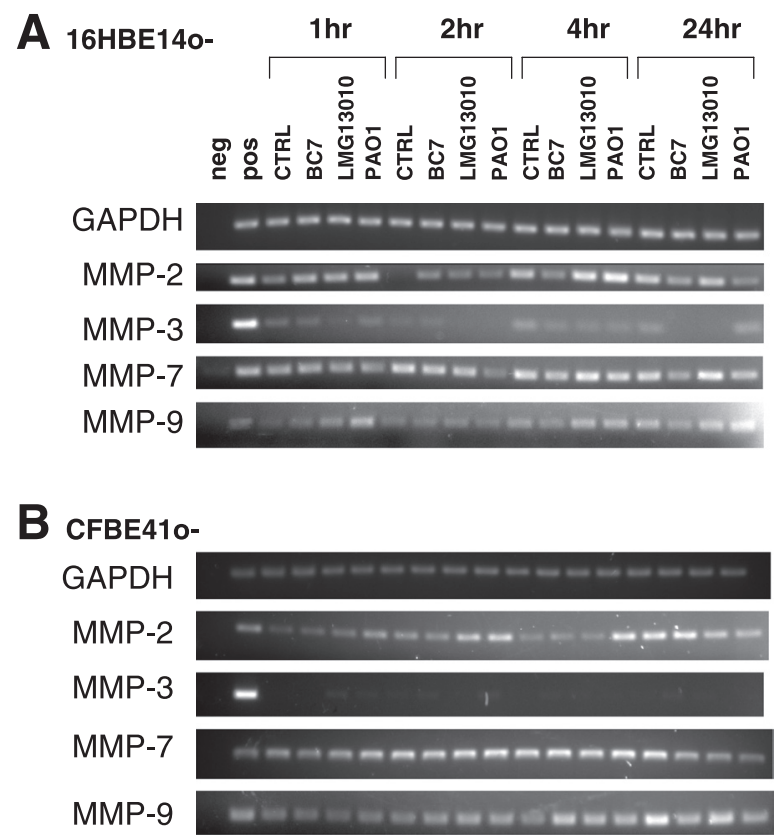

Fig. 1. Upregulation of matrix metalloproteinase (MMP)-2 and MMP-9 genes in response to Burkholderia cepacia complex and Pseudomonas aeruginosa infection by semiquantitative RT-PCR. Confluent monolayers of $16 \mathrm{HBE} 14 \mathrm{o}-$ cells $(A)$ and CFBE41o- cells $(B)$ were exposed to bacteria (multiplicity of infection 50:1) for 1, 2, 4, or $24 \mathrm{~h}$ and the expression of MMP-2, MMP-3, MMP-7, and MMP-9 mRNA was determined by semiquantitative RT-PCR. Upregulation of both MMP-2 and MMP-9 genes is apparent at $2 \mathrm{~h}$ in response to $B$. cepacia complex. No clear upregulation of the MMP-7 gene was observed. Images are representative gels from 2 independent experiments. neg, Negative; pos, positive, CTRL, control cells treated with bacteria-free medium; BC7, B. cenocepacia strain; LMG13010, B. multivorans strain; PAO1, P. aeruginosa strain.

strain LMG13010 also upregulated the MMP-2 gene in $16 \mathrm{HBE} 14 \mathrm{o}-$ cells by 4.6 -fold $(P<0.01)$, there was no statistically significant upregulation in CFBE41o- cells, relative to controls. There was a 2- to 3-fold increase in MMP-7 gene expression in response to both $B$. cepacia complex strains and to PAO1, in $16 \mathrm{HBE} 14 \mathrm{o}-$ cells only. In contrast, there was no MMP-7 response in CFBE41o- cells within $1 \mathrm{~h}$ of infection with any of the three strains examined. B. cenocepacia BC7 infection also resulted in an upregulation of the MMP-9 gene in both cell lines; however, no alteration in MMP-9 gene expression was observed in response to $B$. multivorans strain LMG13010 or to $P$. aeruginosa in either cell line. Interestingly, there was no upregulation of any of the three genes examined in response to $P$. aeruginosa (PAO1) in CFBE41ocells was observed at the early $1 \mathrm{~h}$ time point, but increased expression of both MMP-2 mRNA (6-fold) and MMP-7 mRNA (2.8-fold) was observed in 16HBE14o- cells $(P<$ $0.01)$.

MMP-9 is activated following B. cenocepacia infection. The secreted levels of MMP-2 and MMP-9 were examined by gelatin zymography of conditioned media at 24 and $48 \mathrm{~h}$ (Fig. 3). There was a clear activation of MMP-9 in the presence of B. cenocepacia strain BC7 over $48 \mathrm{~h}$, in the conditioned medium from both the 16HBE14o- cells (3-fold) and CFBE41o- cells (2-fold) (Fig. 3A, $P<0.05$ ). This activation was confirmed by MMP-9-specific fluorometric assay (Fig. 3B), which indicated that a 4-fold and 3.8-fold increase in MMP-9 activity was 
Fig. 2. Expression of MMP genes in response to $B$. cepacia complex and $P$. aeruginosa infection by real-time PCR. 16HBE14o- cells $(A)$ or CFBE41o- cells $(B)$ were infected with $B$. cenocepacia strain BC7, B. multivorans strain LMG13010, or $P$. aeruginosa strain PAO1 for 1 h. MMP-2, MMP-7, and MMP-9 mRNA expression was determined by real-time quantitative PCR relative to GAPDH mRNA. A: upregulation of MMP-2 and MMP-7 mRNA was observed in response to infection with all 3 species, whereas MMP-9 upregulation was only observed in response to $B$. cenocepacia. $B$ : MMP-2 and MMP-9 were both upregulated in response to $B$. cenocepacia infection in CFBE41o- cells. Bars represent the average of 3 separate experiments + SE. *Significant difference in expression from uninfected cells $(P<0.05)$. **Significant difference in expression from uninfected cells $(P<0.01)$.
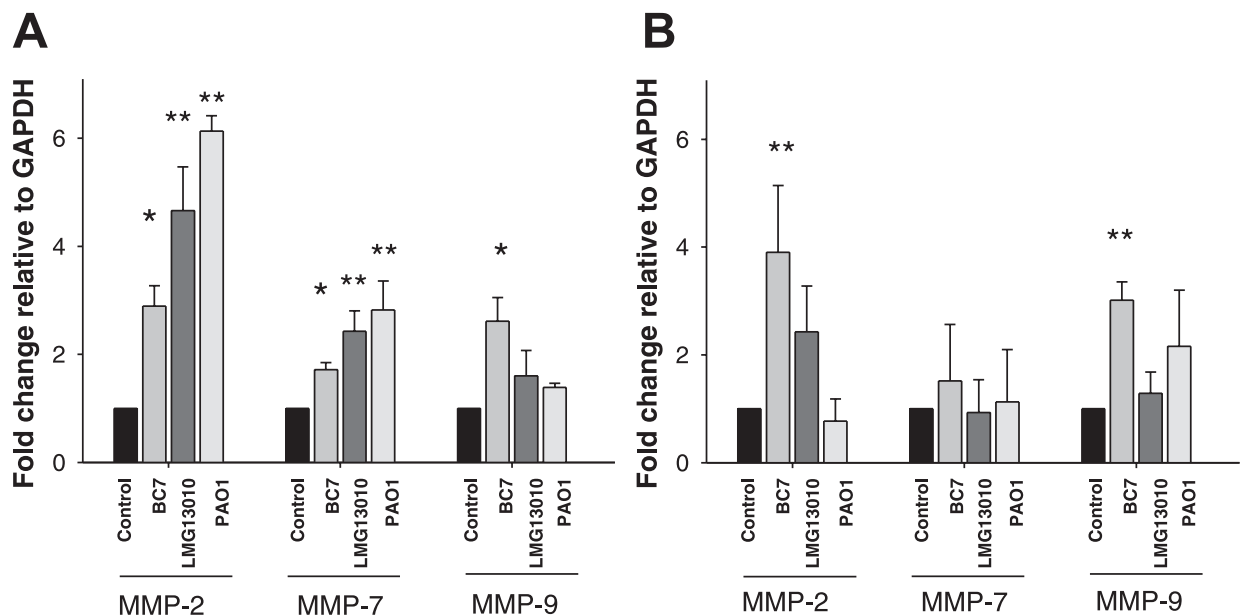

achieved in 16HBE14o - and CFBE41o - cells, respectively $(P<0.05)$. Zymography showed an upregulation of MMP-9 by 1.7 -fold $48 \mathrm{~h}$ following infection of $16 \mathrm{HBE} 14 \mathrm{o}-$ cells with B. multivorans strain LMG13010 (Fig. 3A), but which was not apparent in CFBE41o- cells. Despite the lack of apparent activation of MMP-9 in CFBE41-cells by zymography, quantitation of MMP-9 activity demonstrated a 2.0-fold and 2.4fold increase in MMP-9 activity in 16HBE14o- and CFBE41o- cells $(P<0.05)$ following 48 -h exposure to $B$. multivorans strain LMG13010. The difference in zymography and fluorometric assay may be due to the fact that zymography underestimated the relatively weak MMP-9 activation by $B$. multivorans LMG13010 in CFBE cells. No activation of proMMP-2 was observed for either B. cepacia complex strain. In comparison, much more MMP activation was evident following infection of 16HBE41o- cells with PAO1 (Fig. 3C). When the conditioned medium from PAO1 was applied without dilution to zymography gels, extensive gelatinase activation was observed as seen by a large smear of gelatin degradation (Fig. 3C), and it was difficult to determine which gelatinase was activated. However, dilution of the conditioned medium to 1:100 and below showed that the predominant MMP activated following PAO1 infection was MMP-2 in $16 \mathrm{HBE} 14 \mathrm{o}-$ cells. Comparable studies indicated that CFBE41o- cells also secreted high levels of MMP-2 in response to PAO1 (Fig. 3D).

Secretion of active MMP-9 is observed basolaterally and not apically in polarized lung epithelial cells. To explore the activation in polarized cells, $16 \mathrm{HBE} 14 \mathrm{o}-$ or CFBE41o- cells were cultured on semipermeable Transwell filters. These were infected apically either with B. cenocepacia strain $\mathrm{BC} 7$ or with B. multivorans strain LMG13010, and the filtered conditioned medium from the apical and basolateral compartments was analyzed by zymography. No alteration in MMP expression or activation was observed in the apical supernatants of polarized 16HBE14o - cells or CFBE41o- cells (data not shown). In contrast, basolateral levels of activated MMP-9 were increased following apical infection with B. cenocepacia strain BC7, which was evident up in the basolateral chamber to $72 \mathrm{~h}$ postinfection in both cell lines (Fig. 4, $A$ and $B$ ). Exposure to B. multivorans strain LMG13010 did not have any apparent effect on MMP secretion of the lung cell lines, either basolaterally or apically on zymograms.
MMPs are not involved in B. cepacia complex-related tight junction disruption. We and others have previously shown that coincubation of lung epithelial cells with a series of $B$. cepacia complex isolates resulted in disruption of epithelial integrity, as evidenced by a drop in transepithelial resistance and a reduction in zonula occludens- $1(\mathrm{ZO}-1)$ expression $(9,25)$. To explore whether activation of MMPs were responsible for this effect, we preexposed polarized CFBE41o- cells to the MMP broad-spectrum inhibitor, GM6001, prior to, and during, infection with either B. multivorans strain LMG13010, or the $B$. cenocepacia strain BC7. The concentration used $(10 \mu \mathrm{M})$ is recommended for inhibition of a range of MMPs. Exposure of $16 \mathrm{HBE} 14 \mathrm{o}-$ or CFBE41o - cells to these strains resulted in a drop in TER within $4 \mathrm{~h}$ (Fig. 4C), as we have previously demonstrated for Calu-3 cells. However, inhibition of MMP activity by incubation with GM6001 prior to and during infection with B. cepacia complex strains, did not prevent the tight junction disruption. The drop in TER was comparable with that of the individual strains without inhibitor in both cell lines. This clearly indicates that MMPs are unlikely to have any role in the observed tight junction disruption of B. cepacia complex-infected polarized lung epithelial cells.

MMP-9 slows down wound repair in confluent lung epithelia. To explore what effect B. cepacia complex activation of MMP-9 has on pathogenesis, the effect of activated MMPs on the confluent lung epithelial cells was investigated by use of a wound healing model. Both 16HBE14o- (Fig. 5, $A$ and $C$ ) and CFBE41o- (Fig. 5, $B$ and $D$ ) cells rapidly migrated over the wound in untreated control conditioned media, albeit the rate of migration in CFBE41o- cells was slower than that of 16HBE14o - cells $(P<0.05$ at later time points 4 to $8 \mathrm{~h})$. Conditioned medium from B. cenocepacia strain BC7-infected $16 \mathrm{HBE} 14 \mathrm{o}-$ or CFBE41o- cells reduced the rate of wound repair in both $16 \mathrm{HBE} 14 \mathrm{o}-(P<0.001)$ and $\mathrm{CFBE} 41 \mathrm{o}-$ cells $(P<0.05)$, respectively (Fig. 5). In addition, conditioned medium from $16 \mathrm{HBE} 14 \mathrm{o}-$ cells infected with $B$. multivorans strain LMG13010 also significantly reduced the rate of wound repair in 16HBE14o - cells $(P<0.05)$, but not in CFBE41ocells. The apparent difference in the effect of $B$. multivorans, which has a weaker effect on MMP-9 activity, on wound repair may be linked to the slower rate of repair in CFBE41o- cells. In contrast, application of conditioned medium from PAO1infected cells (diluted 1:500 to normalize for active gelatinase) 
A
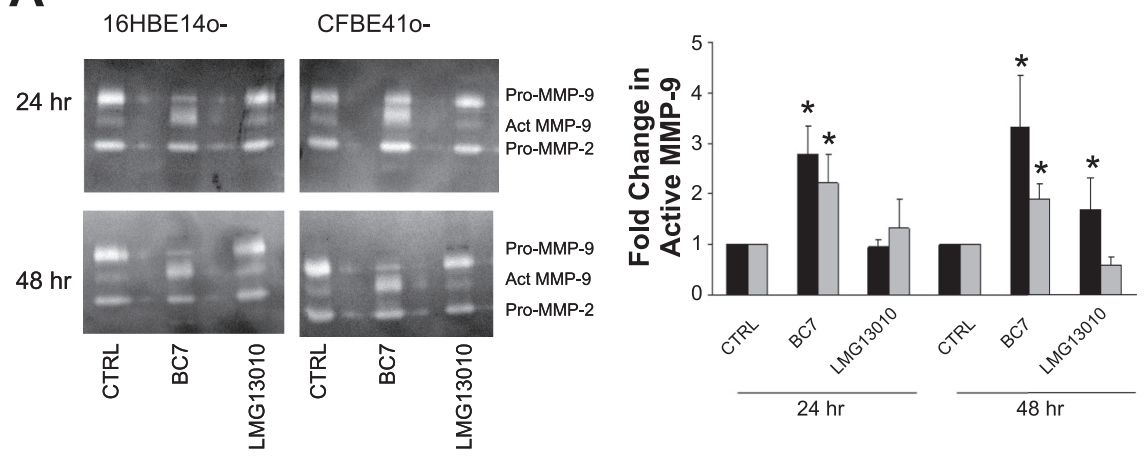

B

Activated MMP-9

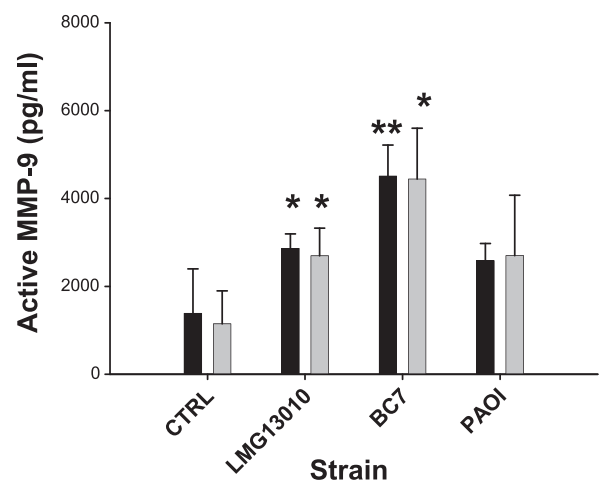

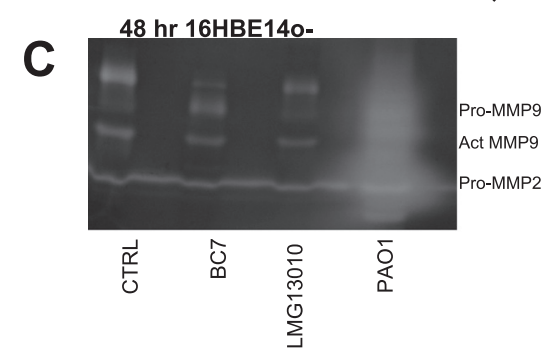

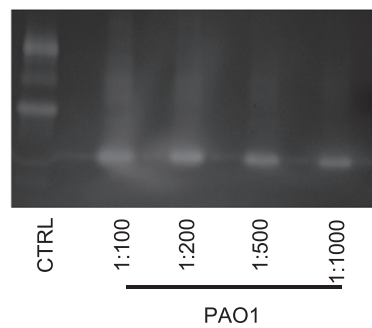

Pro-MMP9

Act MMP9

Pro-MMP2

Act MMP2

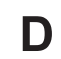

48hr CFBE410-
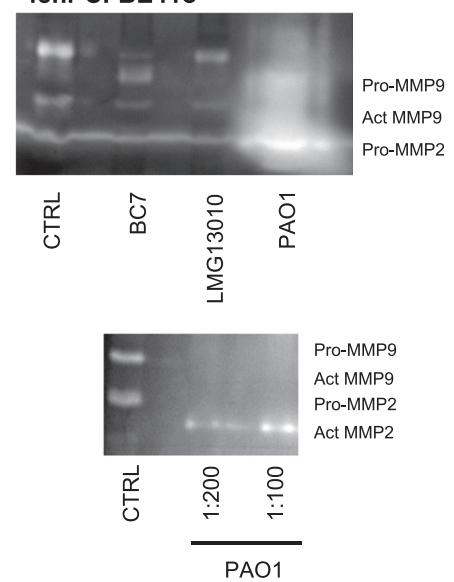

Fig. 3. B. cenocepacia infection increases MMP-9 activity in both cystic fibrosis (CF) and non-CF lung epithelial cells. 16HBE14o- or CFBE41o- cells were treated with bacteria-free medium (CTRL), B. cenocepacia strain BC7, B. multivorans strain LMG13010, or $P$. aeruginosa strain PAO1, for 24 and $48 \mathrm{~h}$. A: representative gelatin zymograms of conditioned media from $B$. cepacia complex-infected cells and corresponding MMP-9 densitometry. Activation of MMP-9 but not MMP-2 was observed compared with control. Densitometry data (solid bars, 16HBE14o-; shaded bars, CFBE 41o-) represent the average of 3 separate experiments and are graphed $\pm \mathrm{SE}$. Act, activated. $*$ Significant difference in expression from uninfected cells $(P<0.05)$. B: MMP-9 activity in 16HBE14o- (solid bars) and CFBE41o(shaded bars) $48 \mathrm{~h}$ after exposure to $B$. cepacia complex or $P$. aeruginosa as determined by fluorometric assay $(* P<0.05, * * P<0.005)$. Data represent means of 3 independent experiments $\pm \mathrm{SD}$. $C$ and $D$ : representative zymogram showing that $16 \mathrm{HBE} 14 \mathrm{o}-$ cells and CFBE41o- cells treated with $P$. aeruginosa strain PAO1 secreted high levels of MMP activity, which required dilution to below 1:100 to observe that the predominant activated MMP was MMP-2. Representative zymograms of 3 independent experiments are shown. did not show any effect on the rate of wound repair in either cell line under the conditions used (Fig. 5).

Specific inhibition of MMP-9 activity was achieved by incubating conditioned cell supernatants with MMP-9 specific inhibitor $(20 \mathrm{nM})$, which is four times the reported $\mathrm{IC}_{50}$ value for MMP-9 inhibition but considerably less than the $\mathrm{IC}_{50}$ values for its two secondary targets MMP-13 or MMP- 1 ( $\mathrm{IC}_{50}$ values of 113 $\mathrm{nM}$ and $1.05 \mu \mathrm{M}$, respectively). This concentration was chosen to ensure complete inhibition of MMP-9 activity. Incubation of conditioned medium from $B$. cenocepacia-treated cells with this inhibitor reduced MMP-9 activity from $4.5 \mathrm{ng} / \mathrm{ml}$ (16HBE14otreated) and $3.3 \mathrm{ng} / \mathrm{ml}$ (CFBE41o - treated) to undetectable levels in both cases as determined by MMP-9 fluorometric assay. When MMP-9 activity was specifically suppressed in conditioned me- dium from B. cenocepacia-infected cells, the delay in wound repair that had been observed was reversed and the wound repair was comparable with that of controls for both cell lines (Fig. 6, $P<0.05$ ). For further confirmation of the role of MMP-9, conditioned media from control monolayers were also treated with $1 \mathrm{mM}$ APMA, a potent activator of MMPs. Zymography verified that there was clear activation of MMP-9 and to a lesser extent MMP-2 in these conditioned media following APMA treatment (Fig. 7A). APMA-treated conditioned media applied to wounded cells also inhibited cell migration and wound repair in both cell lines (Fig. 7, $B$ and $C ; P<0.01$, in both cases), again indicating that the presence of activated MMP-9 prevented epithelial wound repair, rather than an alternative bacterial component. 
A

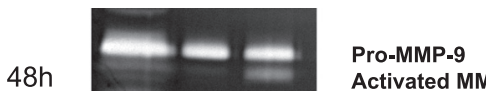
$48 \mathrm{~h}$

$72 \mathrm{~h}$

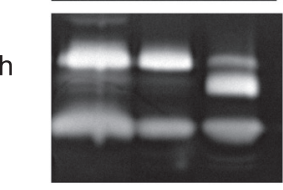

Pro-MMP-9 Activated MMP-9 Pro-MMP-2

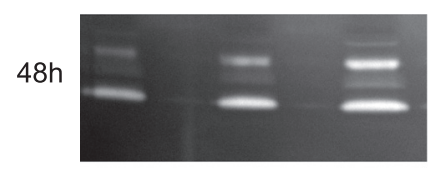

Pro-MMP9 Activated MMP9 Pro-MMP2

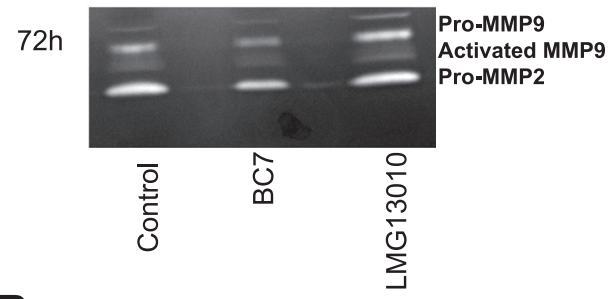

B

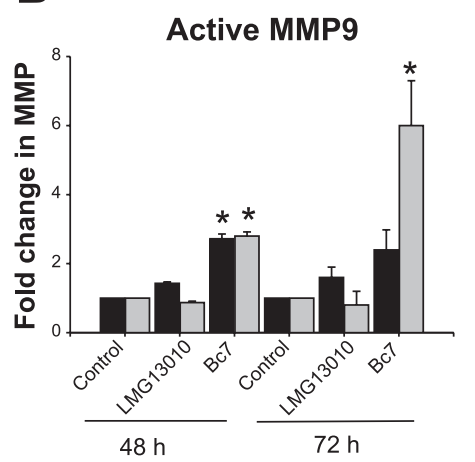

16HBE140-

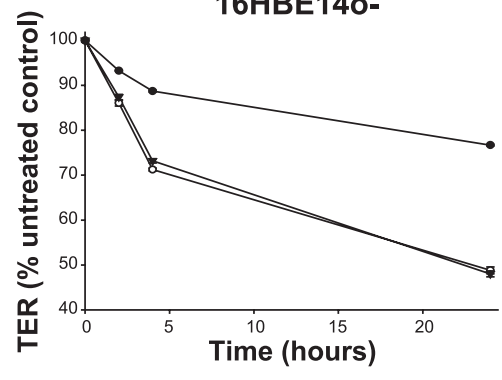

$\longrightarrow$ vehicle control

$\begin{array}{ll}\because & \text { LMG13010 } \\ \longrightarrow & \text { LMG13010 + GM6001 }\end{array}$

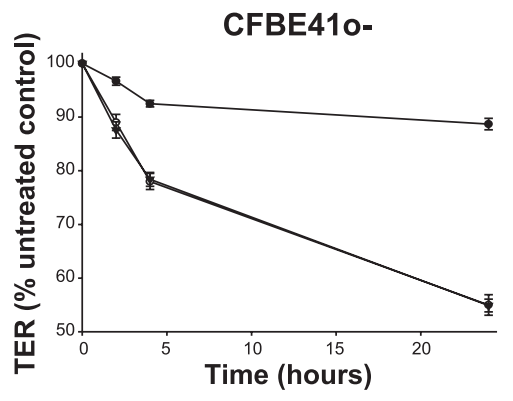

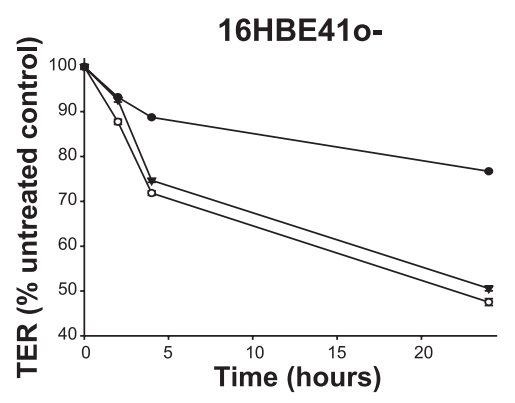

$\longrightarrow$ Vehicle control $\because \mathrm{BC7}$ $\because \mathrm{BC7}+$ BC7 + GM6001

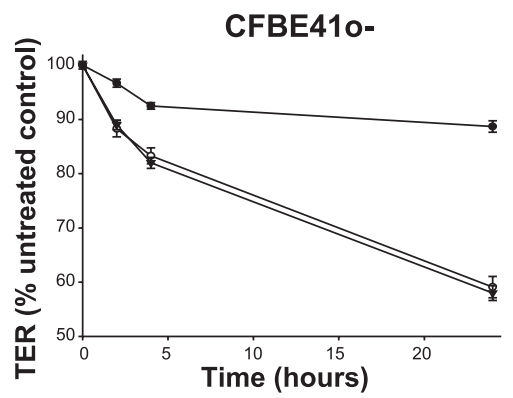

Fig. 4. Basolateral secretion of active MMP-9 from polarized lung epithelial cells and lack of effect of MMPs on tight junction integrity. A: representative gelatin zymograms of conditioned media from basolateral chamber of polarized $16 \mathrm{HBE} 14 \mathrm{o}-$ and CFBE41o - cells 48 and $72 \mathrm{~h}$ after infection with B. multivorans strain LMG13010 or B. cenocepacia strain BC7. B: corresponding densitometry. *Significant change in MMP-9 activity $(P<0.05)$. $C$ : inhibition of MMP activity does not impair B. cepacia complex-induced opening of tight junctions. Polarized 16HBE14o- and CFBE41o- cells were treated with GM6001 before and during infection with B. multivorans LMG13010 or B. cenocepacia BC7 and tight junction integrity was monitored by transepithelial electrical resistance (TER), demonstrating that MMP inhibition does not alter tight junction integrity. Data are presented as $\%$ change in TER relative to medium treated control \pm SE from 3 independent experiments.

\section{DISCUSSION}

B. cenocepacia has been established as the most virulent of all the B. cepacia complex species identified $(31,32)$, being more frequently associated with cepacia syndrome and patient deaths relative to other species in the complex (22). B. cenocepacia also elicits a potent proinflammatory response. Studies have shown that $B$. cepacia complex LPS can elicit up to 10 times more TNF- $\alpha$ and promote more neutrophil burst compared with LPS from other CF pathogens including $P$. aeruginosa $(19,36,52)$. MMPs are widely implicated in airway damage in chronic pulmonary diseases including CF; however, the role of MMPs in the pathogenesis of B. cepacia complex infection has not been examined to date.

The potential for B. cepacia complex infection to affect MMP expression was examined by semiquantitative PCR initially to screen for the upregulation over a wider time frame and include four MMPs. Upregulation of MMP-2 and MMP-9 genes was evident following infection with both $B$. cepacia complex strains and with $P$. aeruginosa; therefore quantitative analysis was carried out on both of these genes together with MMP-7, which has previously been shown to be upregulated in response to $P$. aeruginosa. To focus on the early effects of infection, real-time PCR analysis was carried out on cells at 1 $\mathrm{h}$ postexposure to bacteria. This confirmed the upregulation of the MMP-2, -7 and -9 genes in response to BC7 infection in 16HBE14o - cells. MMP-2 and MMP-9 were also upregulated in the CFBE41o- cells within $1 \mathrm{~h}$. Interestingly, the CFTRexpressing $16 \mathrm{HBE} 14 \mathrm{o}-$ cells were generally more responsive to infection from all three species than the CFBE41o- cells. In particular, MMP-7 gene upregulation was not observed in response to infection with any of the bacteria examined in the CFBE41o- cells within $1 \mathrm{~h}$. MMP-7 is widely reported to be upregulated in response to $P$. aeruginosa expression; however, all the studies have been carried out in CFTR-expressing cells 
A

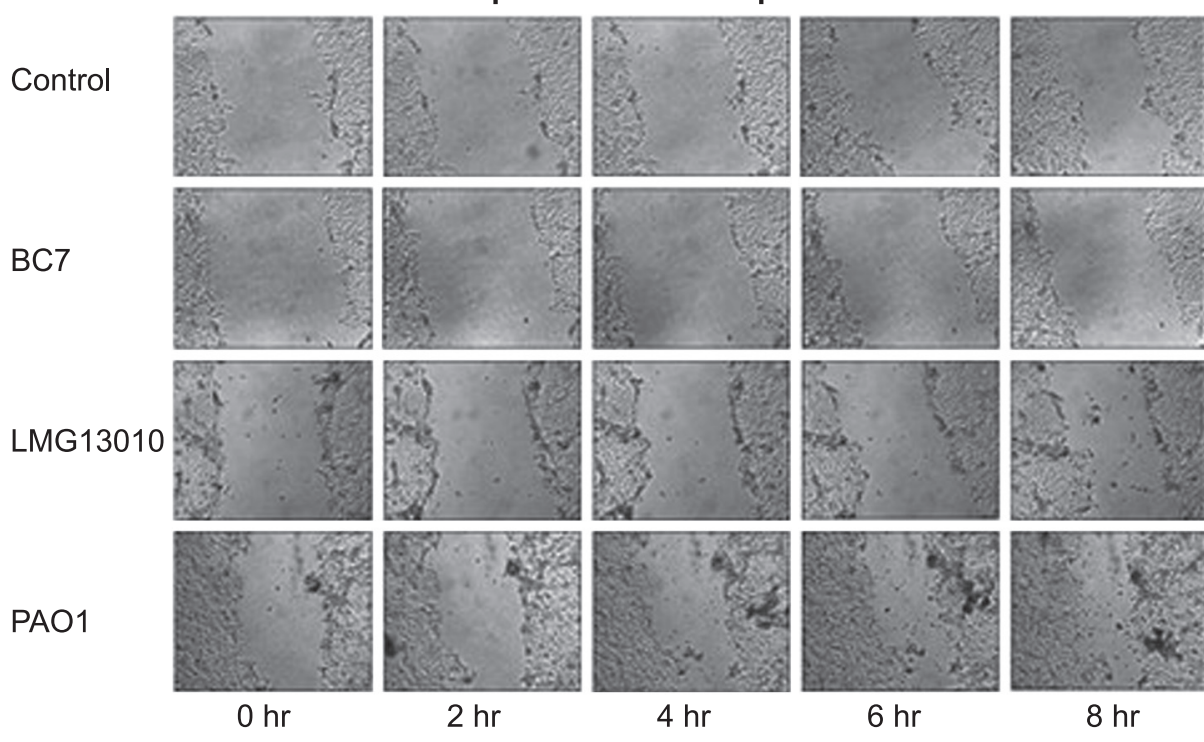

B CFBE410- Wound repair - Bacterial Supernatants

CTRL

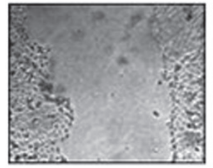

BC7
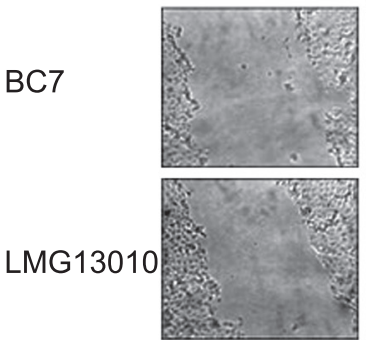

$\mathrm{PAO} 1$

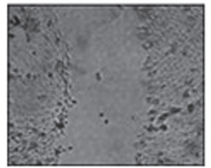

$0 \mathrm{hr}$
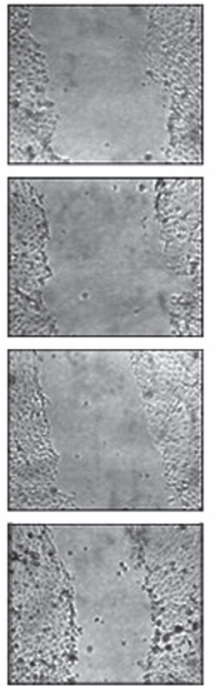

$2 \mathrm{hr}$

\section{16HBE140-}

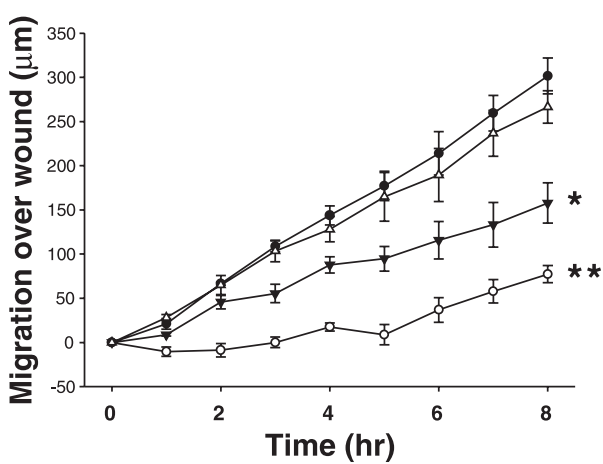

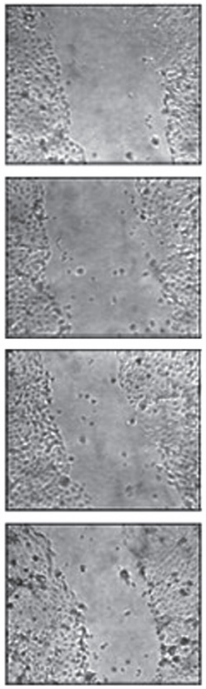

$4 \mathrm{hr}$
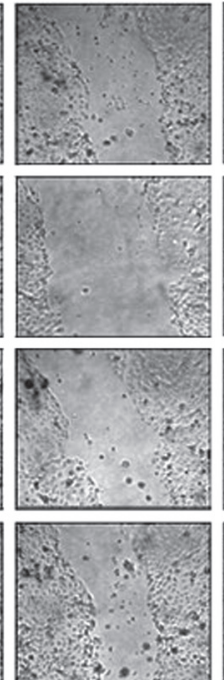

$6 \mathrm{hr}$
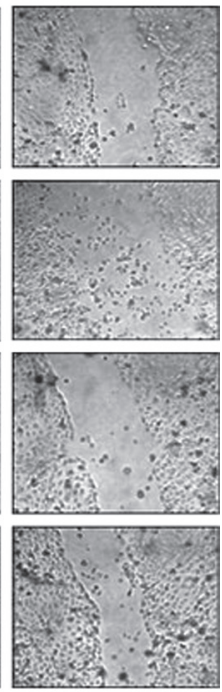

D CFBE410-

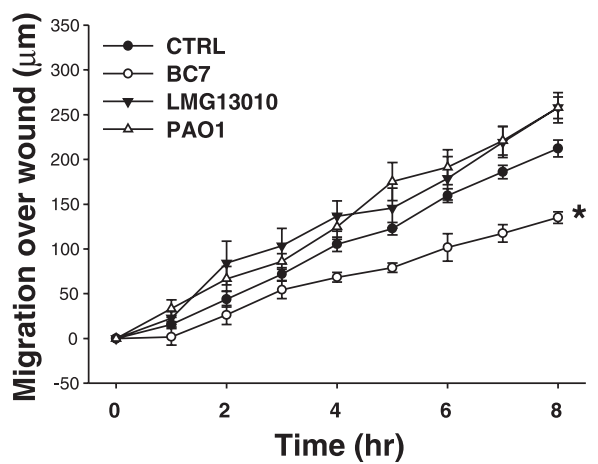

Fig. 5. Effects of bacterial infection on wound repair in lung epithelial cells. Confluent lung epithelial cells were grown for $24 \mathrm{~h}$ and subjected to scrape wounding and allowed to recover over time at $37^{\circ} \mathrm{C}$ and $5 \% \mathrm{CO}_{2}$ in the presence of conditioned media from control cells or from cells infected with $B$. cenocepacia (BC7), B. multivorans (LMG13010), or $P$. aeruginosa (PAO1). $A$ and $B$ : representative phase-contrast images of $16 \mathrm{HBE} 14 \mathrm{o}-(A)$ and CFBE41o- $(B)$ cells were captured at $0,2,4$, 6 , and $8 \mathrm{~h}$ postwounding to illustrate recovery. A delay in recovery was evident in cultures exposed to conditioned media from $B$. cenocepacia BC7-infected cells. $C$ : migration of $16 \mathrm{HBE} 14 \mathrm{o}-$ cells over the wound was measured at hourly intervals and plotted against time. D: migration of CFBE41o- cells over the wound was measured at hourly intervals and plotted against time. Data in $C$ and $D$ are graphed $\pm \mathrm{SE}$ and are representative of 3 independent experiments in each case. Significant difference wound closure following exposure to conditioned medium from infected cells relative to uninfected cells: $* * P<0.01$ $* P<0.05$. 
Fig. 6. Inhibition of MMP-9 activity in conditioned medium from B. cenocepacia-infected cells reverses the delay in wound repair. Confluent lung epithelial cells were grown for $24 \mathrm{~h}$ and subjected to scrape wounding and allowed to recover over time at $37^{\circ} \mathrm{C}$ and $5 \% \mathrm{CO}_{2}$ in the presence of conditioned media from control cells or from cells infected with B. cenocepacia (BC7) in the absence or presence of MMP-9 inhibitor I. $A$ and $B$ : zymography illustrating the inhibition of MMP-9 activation in 16HBE140cells $(A)$ and CFBE41o- cells $(B)$ in the presence of MMP-9 inhibitor 1. $C$ and $D$ : representative phase-contrast images of $16 \mathrm{HBE} 14 \mathrm{o}-$ (A) and CFBE41o- $(B)$ cells were captured at 0,4 , and $8 \mathrm{~h}$ postwounding to illustrate recovery. The delay in recovery evident in cultures exposed to conditioned media from $B$. cenocepacia strain BC7-infected cells was reversed in cultures exposed to conditioned medium from B. cenocepacia strain $\mathrm{BC} 7$-infected cells in the presence of MMP-9 inhibitor I. E: migration of $16 \mathrm{HBE} 14 \mathrm{o}-$ cells over the wound was measured and plotted against time. $F$ : migration of CFBE41o- cells over the wound was measured and plotted against time. Data in $E$ and $F$ are graphed $\pm \mathrm{SE}$ and are representative of 3 independent experiments in each case. Significant difference wound closure following exposure to conditioned medium from infected cells relative to uninfected cells: $* P<0.05$.
A 16HBE140-

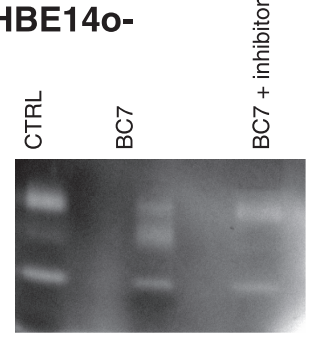

C

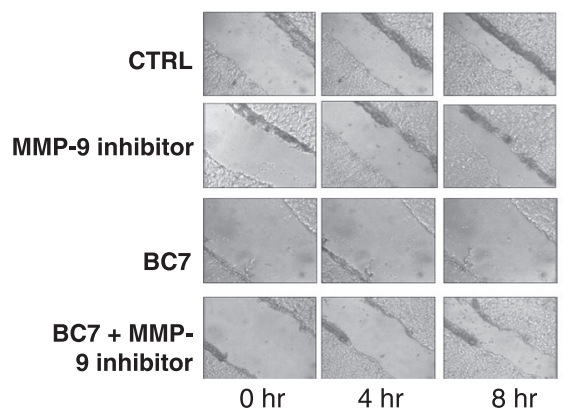

$E$

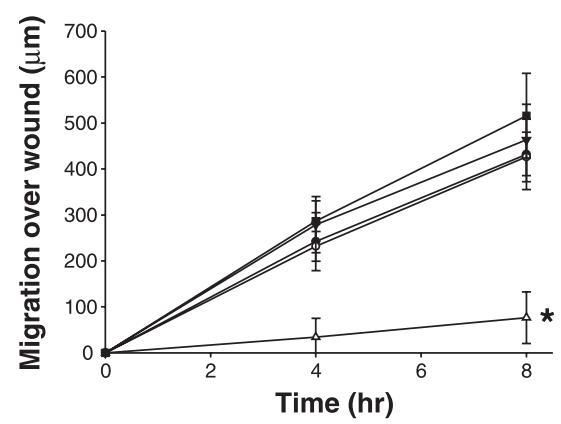

B CFBE410-

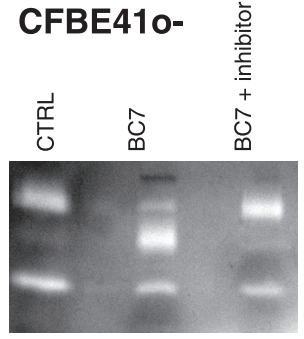

D

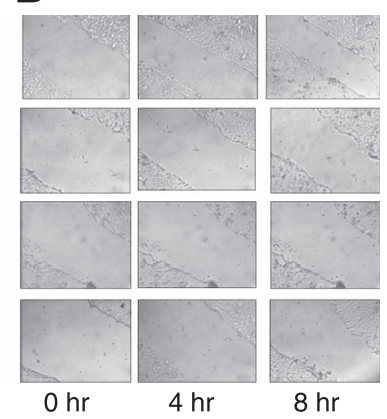

$\mathbf{F}$

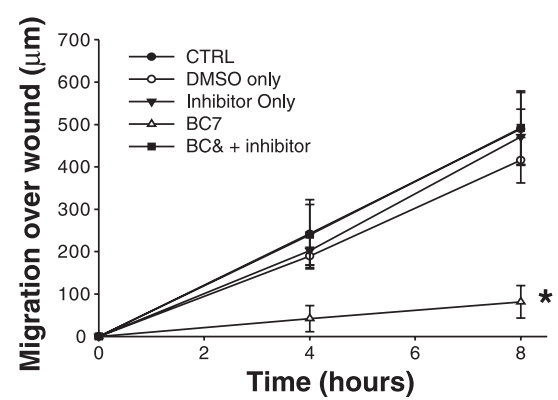

or tissues $(24,30)$. To the best of our knowledge, no study has been carried out to examine the effect of $P$. aeruginos $a$ on MMP-7 expression in cells or tissues with a CF phenotype. It is possible that the MMP-7 upregulation in response to $P$. aeruginosa is CFTR dependent or is slower in cells with a CF phenotype and so should be examined further.

Because of the consistent early upregulation of MMP-2 and MMP-9 genes in both cell lines, with and without a CF phenotype, we focused on the gelatinases for further study. Clear activation of MMP-9 but not MMP-2 in response to $B$. cenocepacia exposure was evident in gelatinase zymography. In addition, we have established that the activation of MMP-9 is polarized and is exclusive to the basolateral side of CFBE41o- monolayers. This is significant because basolateral activation will have most impact on lung tissue following infection, having greater access to the basement membrane components and immune cells. Although the gelatinase activity following $B$. cenocepacia infection was much less than that following $P$. aeruginosa infection, the predominant gelatinase activated following $P$. aeruginosa infection was MMP-2. The activation of MMP-2 in response to $P$. aeruginosa strain PAO1 exposure has previously been shown, although exposure of human airway epithelial cells to supernatants from $P$. aeruginosa strain PAO1 (1\% dilution) did not result in any change in the expression of MMP-9 or MMP-2 genes (7). Our observed upregulation of MMP-2 gene expression is probably due to the fact that we used whole cells, rather than supernatants.

We have previously shown that when $B$. cenocepacia strain BC7 or B. multivorans strain LMG13010 was applied to polarized epithelial cells, the tight junctions were disrupted with concomitant degradation of the tight junction protein ZO-1 (9). Given previous reports relating MMP-9 having activity on the epithelial tight junction protein claudin 1 and subsequent effects on tight junction integrity, we therefore wanted to examine whether MMPs were involved in this previously observed disruption of TER following B. cepacia complex infection. TER is a widely used marker of tight junction integrity, one of several indicators of epithelial barrier disruption. Exposure of polarized $16 \mathrm{HBE} 140-$ or CFBE41ocells to either B. cenocepacia strain BC7 or B. multivorans strain LMG13010, in the presence of GM6001, a broadspectrum inhibitor of MMPs-1, -2, -3, -7 and -9 (1, 14), did not have any effect on tight junction integrity. This suggests that the observed MMP-9 activation following B. cepacia complex infection, or any other inhibited MMPs, did not play a role in this response. The ability for MMPs including MMP-7 and MMP-9 to degrade tight junction and adherens junction proteins has been shown previously. Asahi et al. (2) have suggested that the tight junction protein $\mathrm{ZO}-1$ is a substrate for MMP-9 in a blood-brain barrier model. They showed that 
B 16HBE140-

\section{A APMA Activation}

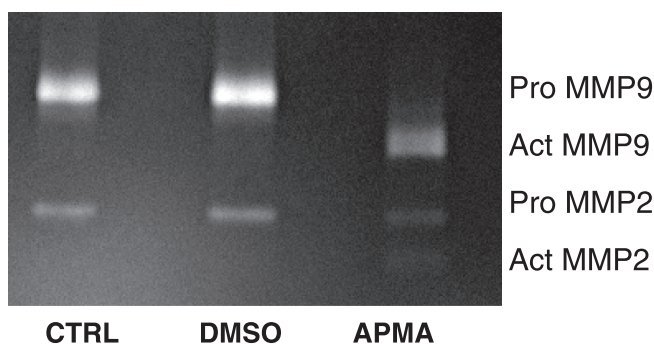

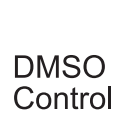
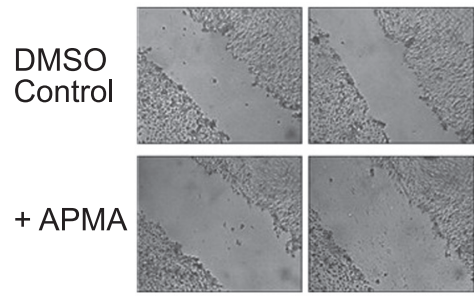

$0 \mathrm{hr}$

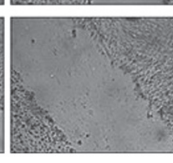

$2 \mathrm{hr}$
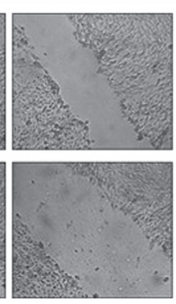

$4 \mathrm{hr}$
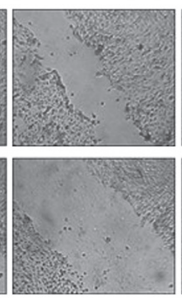

$6 \mathrm{hr}$
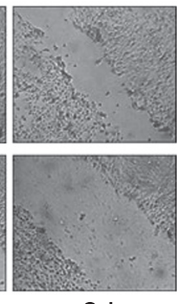

$8 \mathrm{hr}$

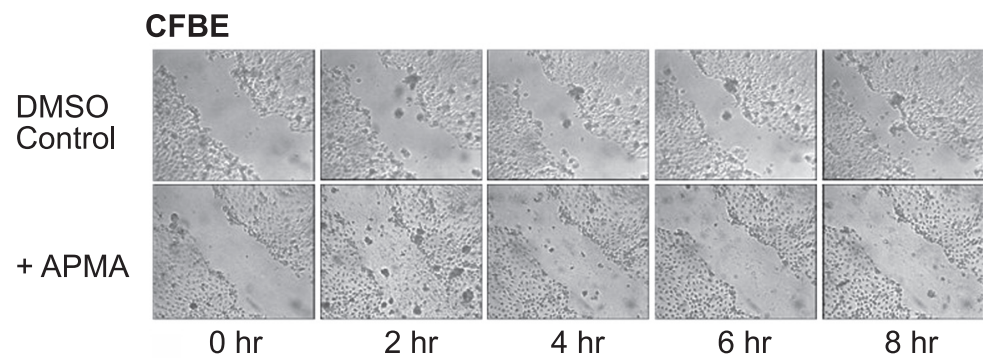

16HBE140-
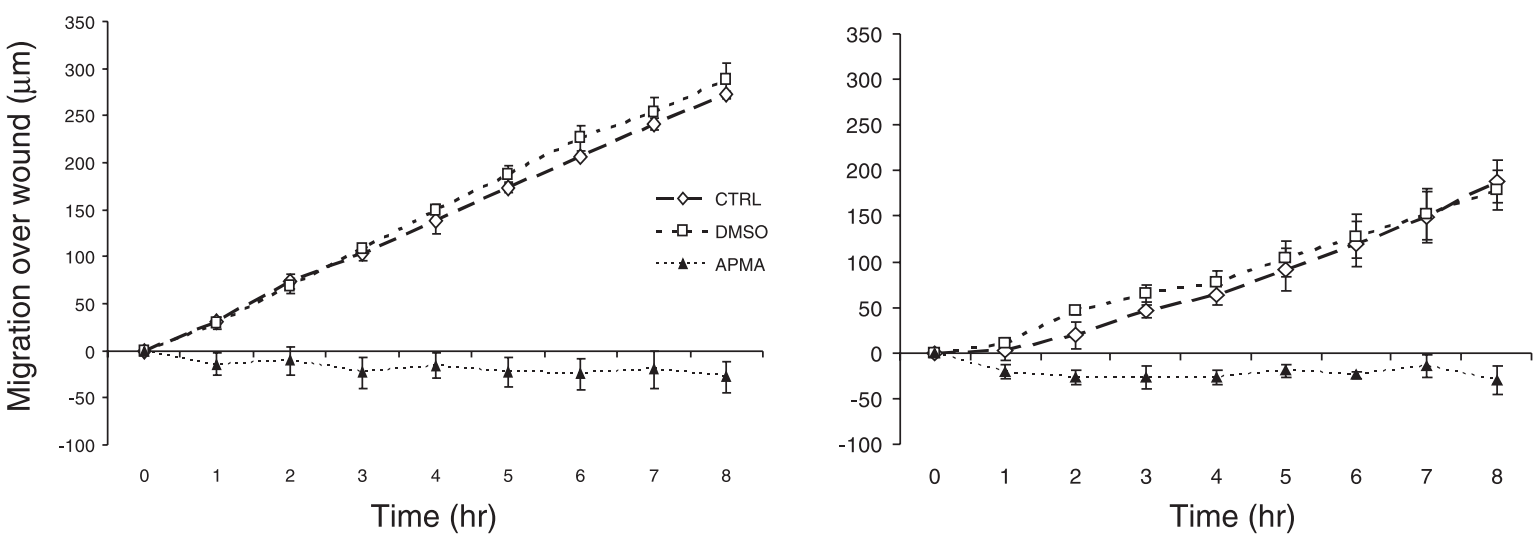

Fig. 7. 4-Aminophenylmercuric acetate (APMA) activation of conditioned medium from uninfected cells results in MMP-9 activation and consequent delay in wound repair. Confluent lung epithelial cells were grown for $24 \mathrm{~h}$ and subjected to scrape wounding and allowed to recover over time at $37^{\circ} \mathrm{C}$ and $5 \% \mathrm{CO}_{2}$ in the presence of conditioned media from control cells with or without APMA pretreatment. A: zymogram of conditioned media from confluent epithelial cells exposed to control medium only (MEM), following exposure to the vehicle only (DMSO) or exposed to APMA. $B$ : representative phase-contrast images of $16 \mathrm{HBE} 14 \mathrm{o}-$ and CFBE41o - cells were captured at $0,2,4,6$, and $8 \mathrm{~h}$ postwounding to illustrate recovery. A delay in recovery was evident in both $16 \mathrm{HBE} 14 \mathrm{o}-$ and CFBEo- cultures exposed to conditioned media treated with APMA. C: migration of $16 \mathrm{HBE} 14 \mathrm{o}-$ cells over the wound was measured at hourly intervals and plotted against time. $D$ : migration of CFBE41o - cells over the wound was measured at hourly intervals and plotted against time for control cells and those exposed to APMA (or DMSO only)-treated conditioned medium. Data in $C$ and $D$ are graphed \pm SE and are representative of 3 independent experiments in each case. * Significant difference wound closure following exposure to conditioned medium following APMA treatment relative to control conditioned media $(P<$ $0.01)$.

ZO-1 degradation, but not occludin degradation, during cerebral ischemia was reduced in MMP- $9^{-1-}$ mice relative to wild type. However, this is a complex model, and many other explanations for this exist. Harkness et al. (17) used confocal microscopy to demonstrate that MMP-9 caused subtle changes in the expression of ZO-1 in the rat endothelium of the central nervous system. In contrast, Ichiyasu et al. (20) have demonstrated that the absence of MMP-9 in knockout mice increased levels of the tight junction regulatory protein, claudin-1, with a concomitant drop in transepithelial migration of dendritic cells. The tight junctions are very tightly regulated, and the degradation of one tight junction protein in isolation cannot be conclusive regarding the integrity of the tight junction complex as a whole. An important feature of tight junctional regulation is that other junctional proteins can compensate for the degradation or lack of a single protein (33). It is clear from our data that MMPs do not contribute to the disruption of tight junctions associated with B. cepacia complex infection.

A delay in wound repair was observed in cells treated with conditioned medium from both cell lines infected with $B$. cenocepacia and with conditioned medium from B. multivorans-infected $16 \mathrm{HBE} 41 \mathrm{o}-$ cells. The finding that specific inhibition of MMP-9 completely reversed this delay in wound repair in both cell lines following $B$. cenocepacia infection strongly suggests that MMP-9 is responsible for the delay in wound repair following $B$. cenocepacia infection. The lack of 
a delay in wound repair in CFBE41o- cells exposed to conditioned medium from $B$. multivorans exposed cells, despite a twofold increase in MMP-9 activity, was unexpected but may relate to the overall slower repair in this particular cell line. A delay in wound repair may have become apparent over a longer period of time. MMPs have been associated both with tissue destruction and with tissue repair $(38-40)$. Olsen et al. (38) have recently demonstrated that exposure of 16HBE14ocells to arsenic upregulated both MMP-9 expression and activity. No alteration in MMP-2 activity was observed. Consistent with our data, the activation of MMP-9 correlated with an impairment of wound repair in confluent monolayers of lung epithelial cells. In addition to delayed wound repair, it is likely that MMP-9 activation may further exacerbate the host response to $B$. cepacia complex infection. It has been shown that high levels of MMP-9 promote infiltration of inflammatory cells and exacerbate the symptoms of asthma (26). In addition, MMP-9 upregulation and activation is expressed during various stages of tuberculosis infection including the tuberculous granuloma, where it is associated with tissue destruction (41). MMP-9 expression was also induced in vivo in mice infected with another respiratory pathogen, Francisella tularensis, and was demonstrated to play a clear role in pathogenesis of this infection, in terms of histopathology, neutrophil recruitment, and proinflammatory response (34). Exposure of 16HBE14ocells to supernatants or mucopurulent material from $\mathrm{CF}$ airways upregulated a number of MMP genes, including MMP-9 but not MMP-2 (42). This effect was downregulated in response to azithromycin. Further roles in proinflammatory activity of MMP-9 have been demonstrated: MMP-9 processing of the proinflammatory cytokine IL- 8 has been shown to increase its chemotactic activity $(46,47)$ and MMP-9 has been shown to activate IL-1 $\beta$ precursor, another mediator of the inflammatory response (21). Gaggar et al. (12) have shown that MMP-9 is involved in a proteolytic cascade that generates the neutrophil chemoattractant proline-glycine-proline (PGP) from collagen, and this peptide is substantially upregulated in CF sputum samples. The further upregulation of MMP-9 in $B$. cenocepacia-colonized patients is likely to further contribute to elevated PGP levels and the subsequent chronic inflammatory response.

MMP-9 levels have also been implicated with poor survival in $P$. aeruginosa pneumonia non-CF patients (10). Bronchoalveolar lavage (BAL) fluid taken from surviving ventilatorassociated pneumonia patients had a lower ratio of MMP-9 to TIMP relative to those that died. In addition, MMP-9 levels progressively declined in patients' BAL in response to antibiotic therapy (10). MMP-9 activity was also elevated in sputa from lung transplant patients, and those with the highest levels of MMP-9 activity were associated with patients with chronic lung transplant rejection (5). Transplanted $\mathrm{CF}$ patients that have been colonized with $B$. cenocepacia have poorer prognosis compared with patients colonized with other members of the complex (8). The activation of MMP-9 in response to $B$. cenocepacia infection together with its likely role in lung damage, shown here, may provide one mechanism whereby $B$. cenocepacia-colonized patients have poorer outcomes on transplant than patients colonized by $B$. cepacia complex species other than B. cenocepacia and is worthy of further study.
The activation of MMP-9, together with the observed delay in wound repair in CFTR-expressing cells following infection with B. multivorans strain LMG13010, may have relevance for patients with CGD. B. multivorans is the most frequently isolated species among CGD patients (13). Furthermore, it was recently shown that $B$. multivorans associated more with cells from CGD patients than from healthy donors, and infection was associated greater levels of proinflammatory cytokines (51). Our data show that MMP-9 activation may also play a role in delayed the repair of lung damage in addition to a role in the inflammatory response in these patients.

In summary, previous studies have shown that the expression of MMP-9 is enhanced in human airway CF epithelium relative to non-CF epithelia and elevated in serum of $\mathrm{CF}$ patients and correlated with pulmonary exacerbations $(16,43)$. The further activation of MMP-9 in response to B. cenocepacia infection and its effect on delaying epithelial repair, as demonstrated here, would contribute to chronic lung damage that is a key feature of CF lung disease and it is likely to further exacerbate inflammation in B. cenocepacia-colonized patients.

\section{ACKNOWLEDGMENTS}

The authors thank Dr. Dieter Gruenert for kindly providing the $16 \mathrm{HBE} 41 \mathrm{o}-$ and CFBE41o- cells.

\section{GRANTS}

This study was supported by the Programme for Research in Third Level Institutions (PRTLI) Cycle 4 (supported by the European Union Regional Development Plan, the Irish Government National Development Plan 20072013 and administered by the Higher Education Authority in Ireland) and by the Technology Sector Research Postgraduate R\&D Skills Programme (PRDSP), Strand III.

\section{DISCLOSURES}

No conflicts of interest, financial or otherwise, are declared by the author(s).

\section{REFERENCES}

1. Agren MS, Mirastschijski U, Karlsmark T, Saarialho-Kere UK. Topical synthetic inhibitor of matrix metalloproteinases delays epidermal regeneration of human wounds. Exp Dermatol 10: 337-348, 2001.

2. Asahi M, Wang X, Mori T, Sumii T, Jung JC, Moskowitz MA, Fini ME, Lo EH. Effects of matrix metalloproteinase-9 gene knock-out on the proteolysis of blood-brain barrier and white matter components after cerebral ischemia. J Neurosci 21: 7724-7732, 2001.

3. Baldwin A, Mahenthiralingam E, Drevinek P, Pope C, Waine DJ, Henry DA, Speert DP, Carter P, Vandamme P, Lipuma JJ, Dowson CG. Elucidating global epidemiology of burkholderia multivorans in cases of cystic fibrosis by multilocus sequence typing. J Clin Microbiol 46: 290-295, 2008.

4. Baldwin A, Mahenthiralingam E, Drevinek P, Vandamme P, Govan JR, Waine DJ, LiPuma JJ, Chiarini L, Dalmastri C, Henry DA, Speert DP, Honeyborne D, Maiden MCJ, Dowson CG. Environmental Burkholderia cepacia complex isolates in human infections. Emerg Infect Dis 13: 458-461, 2007.

5. Beeh KM, Beier J, Kornmann O, Micke P, Buhl R. Sputum levels of metalloproteinase-9 and tissue inhibitor of metalloproteinase-1, and their ratio correlate with airway obstruction in lung transplant recipients: relation to tumor necrosis factor-alpha and interleukin-10. J Heart Lung Transplant 20: 1144-1151, 2001.

6. Cozens AL, Yezzi MJ, Kunzelmann K, Ohrui T, Chin L, Eng K, Finkbeiner WE, Widdicombe JH, Gruenert DC. CFTR expression and chloride secretion in polarized immortal human bronchial epithelial cells. Am J Respir Cell Mol Biol 10: 38-47, 1994.

7. de Bentzmann S, Polette M, Zahm JM, Hinnrasky J, Kileztky C, Bajolet O, Klossek JM, Filloux A, Lazdunski A, Puchelle E. Pseudomonas aeruginosa virulence factors delay airway epithelial wound 
repair by altering the actin cytoskeleton and inducing overactivation of epithelial matrix metalloproteinase-2. Lab Invest 80: 209-219, 2000.

8. De Soyza A, Meachery G, Hester KL, Nicholson A, Parry G, Tocewicz K, Pillay T, Clark S, Lordan JL, Schueler S, Fisher AJ, Dark JH, Gould FK, Corris PA. Lung transplantation for patients with cystic fibrosis and Burkholderia cepacia complex infection: a single-center experience. J Heart Lung Transplant 29: 1395-1404.

9. Duff C, Murphy PG, Callaghan M, McClean S. Differences in invasion and translocation of Burkholderia cepacia complex species in polarised lung epithelial cells in vitro. Microb Pathog 41: 183-192, 2006.

10. El-Solh AA, Amsterdam D, Alhajhusain A, Akinnusi ME, Saliba RG, Lynch SV, Wiener-Kronish JP. Matrix metalloproteases in bronchoalveolar lavage fluid of patients with type III Pseudomonas aeruginosa pneumonia. J Infect 59: 49-55, 2009.

11. Elkington PT, Friedland JS. Matrix metalloproteinases in destructive pulmonary pathology. Thorax 61: 259-266, 2006.

12. Gaggar A, Jackson PL, Noerager BD, O'Reilly PJ, McQuaid DB, Rowe SM, Clancy JP, Blalock JE. A novel proteolytic cascade generates an extracellular matrix-derived chemoattractant in chronic neutrophilic inflammation. J Immunol 180: 5662-5669, 2008.

13. Greenberg DE, Goldberg JB, Stock F, Murray PR, Holland SM, Lipuma JJ. Recurrent Burkholderia infection in patients with chronic granulomatous disease: 11-year experience at a large referral center. Clin Infect Dis 48: 1577-1579, 2009.

14. Grobelny D, Poncz L, Galardy RE. Inhibition of human skin fibroblast collagenase, thermolysin, and Pseudomonas aeruginosa elastase by peptide hydroxamic acids. Biochemistry 31: 7152-7154, 1992.

15. Gruenert DC, Willems M, Cassiman JJ, Frizzell RA. Established cell lines used in cystic fibrosis research. J Cyst Fibros 3, Suppl 2: 191-196, 2004.

16. Hajj R, Lesimple P, Nawrocki-Raby B, Birembaut P, Puchelle E, Coraux C. Human airway surface epithelial regeneration is delayed and abnormal in cystic fibrosis. $J$ Pathol 211: 340-350, 2007.

17. Harkness KA, Adamson P, Sussman JD, Davies-Jones GA, Greenwood J, Woodroofe MN. Dexamethasone regulation of matrix metalloproteinase expression in CNS vascular endothelium. Brain 123: 698-709, 2000.

18. Henry DA, Campbell ME, LiPuma JJ, Speert DP. Identification of Burkholderia cepacia isolates from patients with cystic fibrosis and use of a simple new selective medium. J Clin Microbiol 35: 614-619, 1997.

19. Hughes JE, Stewart J, Barclay GR, Govan JR. Priming of neutrophil respiratory burst activity by lipopolysaccharide from Burkholderia cepacia. Infect Immun 65: 4281-4287, 1997.

20. Ichiyasu H, McCormack JM, McCarthy KM, Dombkowski D, Preffer FI, Schneeberger EE. Matrix metalloproteinase-9-deficient dendritic cells have impaired migration through tracheal epithelial tight junctions. Am J Respir Cell Mol Biol 30: 761-770, 2004.

21. Ito A, Mukaiyama A, Itoh Y, Nagase H, Thogersen IB, Enghild JJ, Sasaguri Y, Mori Y. Degradation of interleukin 1beta by matrix metalloproteinases. J Biol Chem 271: 14657-14660, 1996.

22. Jones AM, Dodd ME, Govan JR, Barcus V, Doherty CJ, Morris J, Webb AK. Burkholderia cenocepacia and Burkholderia multivorans: influence on survival in cystic fibrosis. Thorax 59: 948-951, 2004.

23. Karakoc GB, Inal A, Yilmaz M, Altintas DU, Kendirli SG. Exhaled breath condensate MMP-9 levels in children with bronchiectasis. Pediatr Pulmonol 44: 1010-1016, 2009.

24. Kassim SY, Gharib SA, Mecham BH, Birkland TP, Parks WC, McGuire JK. Individual matrix metalloproteinases control distinct transcriptional responses in airway epithelial cells infected with Pseudomonas aeruginosa. Infect Immun 75: 5640-5650, 2007.

25. Kim JY, Sajjan US, Krasan GP, LiPuma JJ. Disruption of tight junctions during traversal of the respiratory epithelium by Burkholderia cenocepacia. Infect Immun 73: 7107-7112, 2005.

26. Kumagai K, Ohno I, Okada S, Ohkawara Y, Suzuki K, Shinya T, Nagase H, Iwata K, Shirato K. Inhibition of matrix metalloproteinases prevents allergen-induced airway inflammation in a murine model of asthma. J Immunol 162: 4212-4219, 1999.

27. Kunzelmann K, Schwiebert EM, Zeitlin PL, Kuo WL, Stanton BA, Gruenert DC. An immortalized cystic fibrosis tracheal epithelial cell line homozygous for the delta F508 CFTR mutation. Am J Respir Cell Mol Biol 8: 522-529, 1993.

28. Lanone S, Zheng T, Zhu Z, Liu W, Lee CG, Ma B, Chen Q, Homer RJ, Wang J, Rabach LA, Rabach ME, Shipley JM, Shapiro SD, Senior RM, Elias JA. Overlapping and enzyme-specific contributions of matrix metalloproteinases- 9 and -12 in IL-13-induced inflammation and remodeling. J Clin Invest 110: 463-474, 2002.

29. Legrand C, Gilles C, Zahm JM, Polette M, Buisson AC, Kaplan H, Birembaut P, Tournier JM. Airway epithelial cell migration dynamics. MMP-9 role in cell-extracellular matrix remodeling. J Cell Biol 146: 517-529, 1999.

30. Lopez-Boado YS, Wilson CL, Parks WC. Regulation of matrilysin expression in airway epithelial cells by Pseudomonas aeruginosa flagellin. J Biol Chem 276: 41417-41423, 2001.

31. Mahenthiralingam E, Baldwin A, Dowson CG. Burkholderia cepacia complex bacteria: opportunistic pathogens with important natural biology. J Appl Microbiol 104: 1539-1551, 2008.

32. Mahenthiralingam E, Urban TA, Goldberg JB. The multifarious, multireplicon Burkholderia cepacia complex. Nat Rev Microbiol 3: 144-156, 2005 .

33. Maher S, Brayden DJ, Feighery L, McClean S. Cracking the junction: update on the progress of gastrointestinal absorption enhancement in the delivery of poorly absorbed drugs. Crit Rev Ther Drug Carrier Syst 25: 117-168, 2008.

34. Malik M, Bakshi CS, McCabe K, Catlett SV, Shah A, Singh R, Jackson PL, Gaggar A, Metzger DW, Melendez JA, Blalock JE, Sellati TJ. Matrix metalloproteinase 9 activity enhances host susceptibility to pulmonary infection with type A and B strains of Francisella tularensis. J Immunol 178: 1013-1020, 2007.

35. McGuire JK, Li Q, Parks WC. Matrilysin (matrix metalloproteinase-7) mediates E-cadherin ectodomain shedding in injured lung epithelium. Am J Pathol 162: 1831-1843, 2003

36. McKeon S, McClean S, Callaghan M. Macrophage responses to $\mathrm{CF}$ pathogens: JNK MAP kinase signaling by Burkholderia cepacia complex lipopolysaccharide. FEMS Immunol Med Microbiol 60: 36-43, 2010.

37. O'Malley CA. Infection control in cystic fibrosis: cohorting, crosscontamination, and the respiratory therapist. Respir Care 54: 641-657, 2009.

38. Olsen CE, Liguori AE, Zong Y, Lantz RC, Burgess JL, Boitano S. Arsenic upregulates MMP-9 and inhibits wound repair in human airway epithelial cells. Am J Physiol Lung Cell Mol Physiol 295: L293-L302, 2008.

39. Parks WC, Shapiro SD. Matrix metalloproteinases in lung biology. Respir Res 2: 10-19, 2001.

40. Parks WC, Wilson CL, Lopez-Boado YS. Matrix metalloproteinases as modulators of inflammation and innate immunity. Nat Rev Immunol 4: 617-629, 2004.

41. Price NM, Gilman RH, Uddin J, Recavarren S, Friedland JS. Unopposed matrix metalloproteinase- 9 expression in human tuberculous granuloma and the role of TNF-alpha-dependent monocyte networks. J Immunol 171: 5579-5586, 2003.

42. Ribeiro CM, Hurd H, Wu Y, Martino ME, Jones L, Brighton B, Boucher RC, O'Neal WK. Azithromycin treatment alters gene expression in inflammatory, lipid metabolism, and cell cycle pathways in well-differentiated human airway epithelia. PLoS One 4: e5806, 2009.

43. Roderfeld M, Rath T, Schulz R, Seeger W, Tschuschner A, Graf J, Roeb E. Serum matrix metalloproteinases in adult $\mathrm{CF}$ patients: relation to pulmonary exacerbation. J Cyst Fibros 8: 338-347, 2009.

44. Speert DP. Advances in Burkholderia cepacia complex. Paediatr Respir Rev 3: 230-235, 2002.

45. Taylor JL, Hattle JM, Dreitz SA, Troudt JM, Izzo LS, Basaraba RJ, Orme IM, Matrisian LM, Izzo AA. Role for matrix metalloproteinase 9 in granuloma formation during pulmonary Mycobacterium tuberculosis infection. Infect Immun 74: 6135-6144, 2006.

46. Van den Steen PE, Proost P, Wuyts A, Van Damme J, Opdenakker G. Neutrophil gelatinase B potentiates interleukin- 8 tenfold by aminoterminal processing, whereas it degrades CTAP-III, PF-4, and GRO-alpha and leaves RANTES and MCP-2 intact. Blood 96: 2673-2681, 2000.

47. Van Den Steen PE, Wuyts A, Husson SJ, Proost P, Van Damme J, Opdenakker G. Gelatinase B/MMP-9 and neutrophil collagenase/MMP-8 process the chemokines human GCP-2/CXCL6, ENA-78/CXCL5 and mouse GCP-2/LIX and modulate their physiological activities. Eur $J$ Biochem 270: 3739-3749, 2003.

48. Vanlaere E, Baldwin A, Gevers D, Henry D, De Brandt E, LiPuma JJ, Mahenthiralingam E, Speert DP, Dowson C, Vandamme P. Taxon K, a complex within the Burkholderia cepacia complex, comprises at least two novel species, Burkholderia contaminans sp. nov. and Burkholderia lata sp. nov. Int J Syst Evol Microbiol 59: 102-111, 2009. 
49. Vanlaere E, Lipuma JJ, Baldwin A, Henry D, De Brandt E, Mahenthiralingam E, Speert D, Dowson C, Vandamme P. Burkholderia latens sp. nov., Burkholderia diffusa sp. nov., Burkholderia arboris sp. nov., Burkholderia seminalis sp. nov. and Burkholderia metallica sp. nov., novel species within the Burkholderia cepacia complex. Int J Syst Evol Microbiol 58: 1580-1590, 2008.

50. Yang Y, Estrada EY, Thompson JF, Liu W, Rosenberg GA. Matrix metalloproteinase-mediated disruption of tight junction proteins in cerebral vessels is reversed by synthetic matrix metalloproteinase inhibitor in focal ischemia in rat. J Cereb Blood Flow Metab 27: 697-709, 2007.
51. Zelazny AM, Ding L, Elloumi HZ, Brinster LR, Benedetti F, Czapiga M, Ulrich RL, Ballentine SJ, Goldberg JB, Sampaio EP, Holland SM. Virulence and cellular interactions of Burkholderia multivorans in chronic granulomatous disease. Infect Immun 77: 4337-4344, 2009.

52. Zughaier SM, Ryley HC, Jackson SK. Lipopolysaccharide (LPS) from Burkholderia cepacia is more active than LPS from Pseudomonas aeruginosa and Stenotrophomonas maltophilia in stimulating tumor necrosis factor alpha from human monocytes. Infect Immun 67: 1505-1507, 1999.

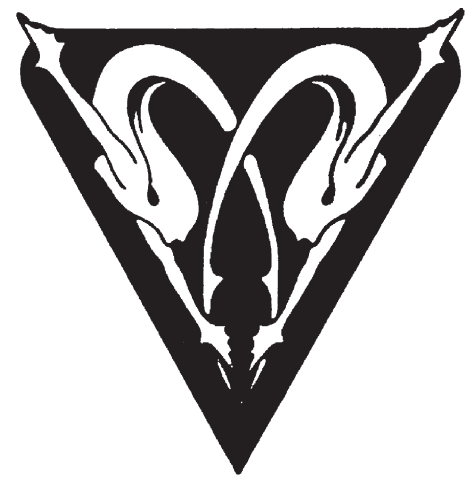

